IFAS EXTENSION

\title{
Alimentación Saludable Para Personas De Edad: Creación De Comidas Sin Necesidad De Cocinar ${ }^{1}$
}

Jennifer Hillan $^{2}$

¿Qué hay de comer cuando usted no tiene ganas de ENAFS cocinar? Piense en alimentos que se puedan usar para una comida balanceada y que no necesiten ser cocinados. Después, ponga estos alimentos en el lugar que les corresponda en la pirámide.

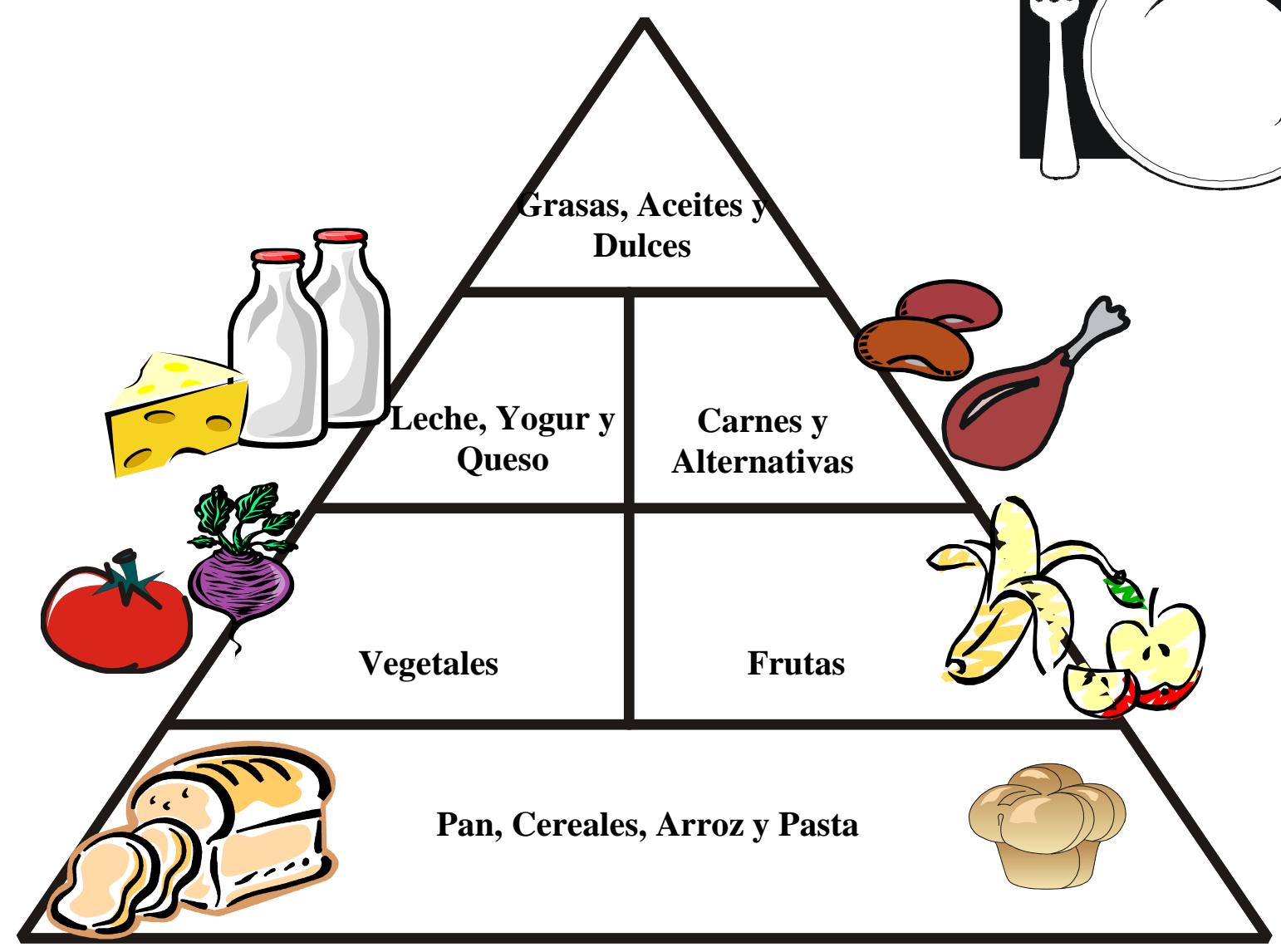

Cómo encaja su comida en la pirámide de alimentos? ¿Está su comida balanceada? ¿Contiene alimentos de al menos tres de los grupos de alimentos básicos (sin incluir grasas, aceites y dulces)? Si no es así, haga los cambios necesarios. Si ha usado alimentos de tres de los grupos básicos, usted habrá creado una comida balanceada. ¡A hora ya puede incorporarla a su dieta!

1. This document, FCS8692-Span, is one in a series of the Department of Family, Youth and Community Sciences, Florida Cooperative Extension Service, Institute of Food and Agricultural Sciences, University of Florida, Gainesville, FL 32611. Publication date: March 2004. The English version of this Spanish language leaflet is Healthy Eating for Elders: Creating a No-Cook Meal. This leaflet was developed with funding from the Florida Department of Elder Affairs in partnership with state, county, and local agencies. Please visit the EDIS Web site at http://edis.ifas.ufl.edu

2. Jennifer Hillan, MSH, RD, LD/N, former ENAFS nutrition educator/trainer, Department of Family, Youth and Community Sciences, Institute of Food and Agricultural Sciences, University of Florida, Gainesville, FL 32611. English version reviewed by Linda B. Bobroff, PhD, RD, LD/N, professor, University of Florida. Translated by Sergio Romero, MS, ATC, University of Florida. Translation reviewed by Isabel Valentín-Oquendo, MS, RD, former FNP curriculum coordinator, University of Florida. 